\title{
MODEL SERTIFIKASI PAMONG \\ PENDIDIKAN ANAK USIA DINI (PAUD) \\ PADA JALUR PENDIDIKAN NON FORMAL
}

\section{Supriyanta}

\section{ABSTRAK}

P

rhatian terhadap anak usia prasekolah, harus didasarkan pada minat terhadap anak dan pemahaman yang mendalam terhadap anak itu sendiri, karena masa kanakkanak adalah masa keemasan yang akan menentukan perkembangan anak selanjutnya.

(The attention for the child of the preschool, have tobase on the best interest and the deep insight of the chlid its selt, because the child period is the golden age that are to diterminate of the child development continuing)

Kata Kunci : PAUD, Model Sertifikasi Pamong

\section{PENDAHULUAN}

Kesadaran akan pentingnya pendidikan anak dini usia telah mendorong pemerintah, dalam hal ini Departemen Pendidikan Nasional melalui Direktorat PADU diharapkan mampu mendorong dan memfasilitasi terbentuknya lembaga pendidikan anak dini usia yang dilaksanakan melalui Kelompok Bermain, Taman Penitipan Anak, dan Kelompok Pendidikan anak usia dini sejenis. Apalagi ketika ditengarai bahwa partisipasi perempuan di sekor publikmakin meningkat, sehingga sangat dimungkinkan perhatian orang tua terhadap anak berkurang.

Terdapat dua alasan penting yang perlu dipahami ketika membicarakan latar belakang keterlibatan wanita dalam angkatan kerja. Pertama, adalah keharusan, sebagai tuntutan dari kondisi ekonomi rumah tangga yang rendah, sehingga bekerja untuk meningkatkan pendapatan rumah tangga menjadi penting. Kedua, karena motivasi tertentu seperti : mengisi waktu luang, mencari kepuasan diri dan aktualisasi diri.

Melihat betapa kurangnya waktu yang dimiliki oleh orang tua untuk melakukan pengasuhan kepada putraputrinya maka penyelenggaraan Taman Penitipan Anak (TPA) ataupun kelompok Bermaik sangatlah diperlukan. Agar penyelenggaraan pendidikan anak usia dini dapat berjalan dengan baik, tidak dapat dipungkiri bahwa keberadaan menu asuhan sangat diperlukan. Dengan adanya menu asuhan pembelajaran ini, pengasuh dan pendidikan di TPA dapat memberikan layanan pengasuhan dan pendidikan sesuai dengan kelompok umur anak, sehingga proses pembelajaran yang dilaksanakan sesuai dengan tumbuh kembang anak.

Undang-Undang No.20 Tahun 2003 tentang Sistem Pendidikan Nasional, Bab I pasal 1 ayat 14 dan bagian ketujuh pasal 28 ayat 1-5 memberikan penjelasan tentang 
Pendidikan Anak Usia Dini. Diantaranya dinyatakan bahwa pendidikan anak usia dini merupakan upaya pembinaan yang ditujukan kepada anak-anak sejak lahir sampai usia enam tahun. Semuanya itu dimaksudkan untuk mempersiapkan generasi mendatang menjadi lebih berkualitas.

Untuk merealisasikan undangundang tersebut diperlukan tindak lanjut khususnya dalam melaksanakan dan mengelola PAUD, yaitu keberadaan tenaga pengelola dan Pamong Belajar/pengasuh yang profesional. Salah satu upaya mempercepat proses dan mewujudkan maksud tersebut, maka program sertifikasi merupakan salah satu jalan keluar yang tepat, karena program ini akan mempersiapkan tenaga pengelola dan pamong belajar/ pengasuh yang memiliki kualifikasi sebagai pengelola dan pendidik bagi anak usia dini.

Pelaksanaan sertifikasi ini juga dikaitkan dengan UU No 20 tahun 2003 khususnya pasal 42 ayat 1 , yang menjelaskan bahwa pendidik (sekolah maupun uar sekolah) harus memiliki kualifikasi minimum dan sertifikasi yang sesuai dengan jenjang kewenangan mengajar, yang dihasilkan oleh perguruan tinggi. Perguruan Tinggi sebagai lembaga tinggi memiliki kewenangan mengeluarkan sertifikat bagi peserta pelatihan tertentu yang dinyatakan memenuhi persyaratan sesuai ketentuan.

Manusia membutuhkan pendidikan dalam kehidupannya, karena pendidikan adalah upaya menuntun segala kekuatan kodrat yang ada pada anak-anak itu, 'agar mereka sebagai manusia dan sebagai anggota masyarakat dapatlah mendapat keselamatan dan kebahagiaan yang setinggitingginya” (Majelis Luhur Persatuan Taman Siswa, 1962). Menurut UU No. 20/2003 pendidikan merupakan usaha sadar dan terencana untuk mewujudkan suasana belajar dan proses pembelajaran agar peserta didik secara aktif mengembangkan potensi dirinya untuk memiliki kekuatan spiritual, keagamaan, pengendalian diri, kepribadian, kecerdasan, akhlak mulia, serta keterampilan yang diperlukan dirinya, masyarakat, bangsa, dan negara (UU No 20/2003, ps 1 ay. 1).

Secara singkat dijeaskan bahwa sistem pendidikan nasional memberikan kesempatan pendidikan bagi semua warga negara dalam mengembangkan kemampuan dan meningkatkan mutu kehidupan dan martabatnya sebagai manusia beradab dan berbudaya dalam rangka mewujudkan tujuan nasional (Dirjen Dikdasmen, 1991; Fuad, 1991). Ini berarti bahwa sistem pendidikan nasional harus mampu menjamin pemerataan kesempatan pendidikan, peningkatan mutu serta relevansi dan efisiensi manajemen pendidikan untuk menghadapi tantangan sesuai dengan tuntutan perubahan kehidupan lokal, nasional, dan global sehingga perlu dilakukan pembaharuan pendidikan secara terencana, terarah, dan berkesinambungan.

Dengan melewati proses pendidikan diharapkan anak-anak akan di"matang"kan untuk bisa menjadi anggota masyarakat yang baik. Proses pematanganpematangan semacam itu akan dapat membawa peserta didik sebagai generasi peserta yang potensial dalam kehidupan 
sehari-hari ditengah masyarakat yang luas.dengan berkembangnya potensi-potensi yang ada maka akan siap untuk mendukung nilai-nilai eksternal maupun nilai-nilai internal yang ada dalam masyarakatnya. Hal ini akan merupakan pertanda bahwa generasi sudah siap untuk menggantikan generasi tua.

Pendidikan Anak Usia Dini atau disingkat PAUD adalah suatu upaya pembinaan yang ditujukan bagi anak sejak lahir sampai dengan usia enam tahun yang dilakukan melalui pemberian rangsangan pendidikan untuk membantu pertumbuhan dan perkembangan jasmani dan rohani agar anak memiliki kesiapan dalam memasuki pendidikan lebih lanjut. Pendidikan anak usia dini merupakan salah satu bentuk penyelenggaraan pendidikan yang menitikberatkan pada peletakan dasar ke arah pertumbuhan dan perkembangan fisik (koordinasi motorik halus dan kasar), kecerdasan (daya pikir, daya cipta, kecerdasan emosi, kecerdasan spiritual), sosio emosional (sikap dan perilaku serta agama) bahasa dan komunikasi, sesuai dengan keunikan dan tahap-tahap perkembangan yang dilalui oleh anak usia dini.

Ada dua tujuan diselenggarakannya pendidikan anak usia dini yaitu: Tujuan utama: untuk membentuk anak Indonesia yang berkualitas, yaitu anak yang tumbuh dan berkembang sesuai dengan tingkat perkembangannya sehingga memiliki kesiapan yang optimal di dalam memasuki pendidikan dasar serta mengarungi kehidupan di masa dewasa. Tujuan penyerta yaitu untuk membantu menyiapkan anak mencapai kesiapan belajar (akademik) di sekolah.

Kemampuan mengembangkan diri pada anak tidaklah terbentuk dengan sendirinya, melainkan perlu campur tangan orang dewasa. Campur tangan bukan dalam arti menguasai dan memaksakan kehendak orang dewasa kepada anak, melainkan mendorong anak untuk membentuk diri sendiri.

Membentuk diri sendiri dalam arti mengembangkan semua potensi aspek kepribadian baik yang menyangkut aspek cipta (pikir), rasa, karsa (kehendak), maupun karya, bisa tercapai melalui proses pendidikan. Kebutuhan akan pendidikan berkenaan dengan semua kebutuhan pengembangan aspek-aspek tersebut di atas, atau dengan kata lain pendidikan menyangkut totalitas perkembangan anak.

$$
\text { Edelman Borden (1997) }
$$

menyatakan bahwa kesadaran akan pentingnya pendidikan usia dini saat ini semakin marak dimana-mana. Hal ini ditandai oleh adanya fenomena dimana setiap tahun sekitar dua setengah juta anak memasuki prasekolah, yang lebih dari separo dikelola oleh swasta.

Dinamika kehidupan masyarakat dan kebutuhan anak akan pendidikan menuntut pelembagaan upaya pendidikan secara formal. Bentuk yang dimaksud adalah bentuk lembaga pendidikan persekolahan maupun lembaga pendidikan luar sekolah sebagai wujud dari upaya sistematik untuk membantu anak mengembangkan diri secara optimal di dalam kehidupan bermasyarakat 
Kenyataam menunjukkan bahwa tuntutan hidup bagi makhluk manusia merupakan tuntutam yang paling berat dan semakin berat sejajar dengan perkembangan đan kemajuan taraff hidupnya. Tuntutam hidup manusia đari zaman ke zaman semakin berkembang, semakin sulit, semakin kompleks, dam terjadi di dalamnya percepatan yang luar biasa dibandingkan dengan tuntutan makhluk hidup yang lain.

Oleh karena itu bayi dan manusia muda tidak akan bisa hidup yang layak kalau hanya mengandalkan potensi nalurinya saja tampa adanya usaha sadar untuk berjuang dan menyesuaikan diri dengan perkembangan tuntutan zaman. Usaha sadar bertolak juga pada hal yang bersifat naluriah juga, yaitu adanya kasih sayang orang tua terhadap anaknya dan tanggung jawab untuk membantu anaknya mempersiapkan dirinya untuk hidup yang layak. Rasa kasih sayang dan tanggung jawab inilah yang menimbulkan salah satu kegiatan dalam hidup manusia yang berupa perlindungan, pemeliharaan, dan bimbingan, yang kemudian disebut kegiatan pendidikan.

Anak-anak pertama-tama mendapatkan pendidikan adalah dalam lingkungan keluarga. Pendidikan yang pertama-tama diterima oleh anak-anak adalah pendidikan dilingkungan keluarga. Pendidik dalam lingkungan keluarga adalah orang tua (bapak dan ibu). Oleh karena itu orangtua biasa mendapat predikat pendidik yang pertama dan utama. Dikatakan pendidik pertama karena pertama-tama anak mendapatkan pendidikan adalah pendidikan dari orangtua mereka sebelum anak-anak memasuki lingkungan-limgkungan pendidikan yang lain. Orangtua juga dikatakan sebagai pendidik utama karena terletak pada orang tualah, tanggung jawab pendidikan anak-anaknya.

\section{METODE PENELITIAN}

Pemelitian ini bertujuan untuk menemukan model sertifikasi pengasuh program pendidikan anak usia dini (PAUD), sehingga akan dihasilkan para pengelola yang memiliki kualifikasi yang sesuai dengan persyaratan, dan pada gilirannya para pengasuh tersebut mampu menghasilkan generasi penerus yang handal dan berkualitas tinggi.

Penelitian menggunakan pendekatan penelitian pengembangan (development research) dalam rangka menghasilkan suatu model sertifikasi pengasuh pada Pendidikan anak usia dini. Dalam penelitian pengembangan ini, beberapa tahapan dilakukan antara lain: Mengidentifikasi masalah yang ada, melakukan analisis potensi, sumber yang tersedia, menyusun prototipe melalui semiloka, dan melakukan Evaluasi Formatif terhadap prototipe yang ada lewat pakar \& praktisi

Sasaran penelitian ini adalah para pengasuh (calon pengasuh) atau yang disebut pamong belajar pada program PAUD, dengan mengambil lokasi di Kabupaten Situbondo, sebagai kabupaten yang ditengarai tingkat pendidikan masyarakatnya relative rendah . Penelitian ini difokuskan pada model sertifikasi program PAUD melalui jalur pendidikan nonformal 
Dalam rangka validasi prototipe model dilakukan verifikasi oleh para pakar, mereka adalah:

1. Praktisi Play Group

2. Praktisi Kelompok Bermain
3. Ahli psikologi anak

4. Ahli pendidikan

5. Tokoh masyarakat yang peduli pendidikan anak

Langkah pengembangan dapat digambarkan sebagai berikut :

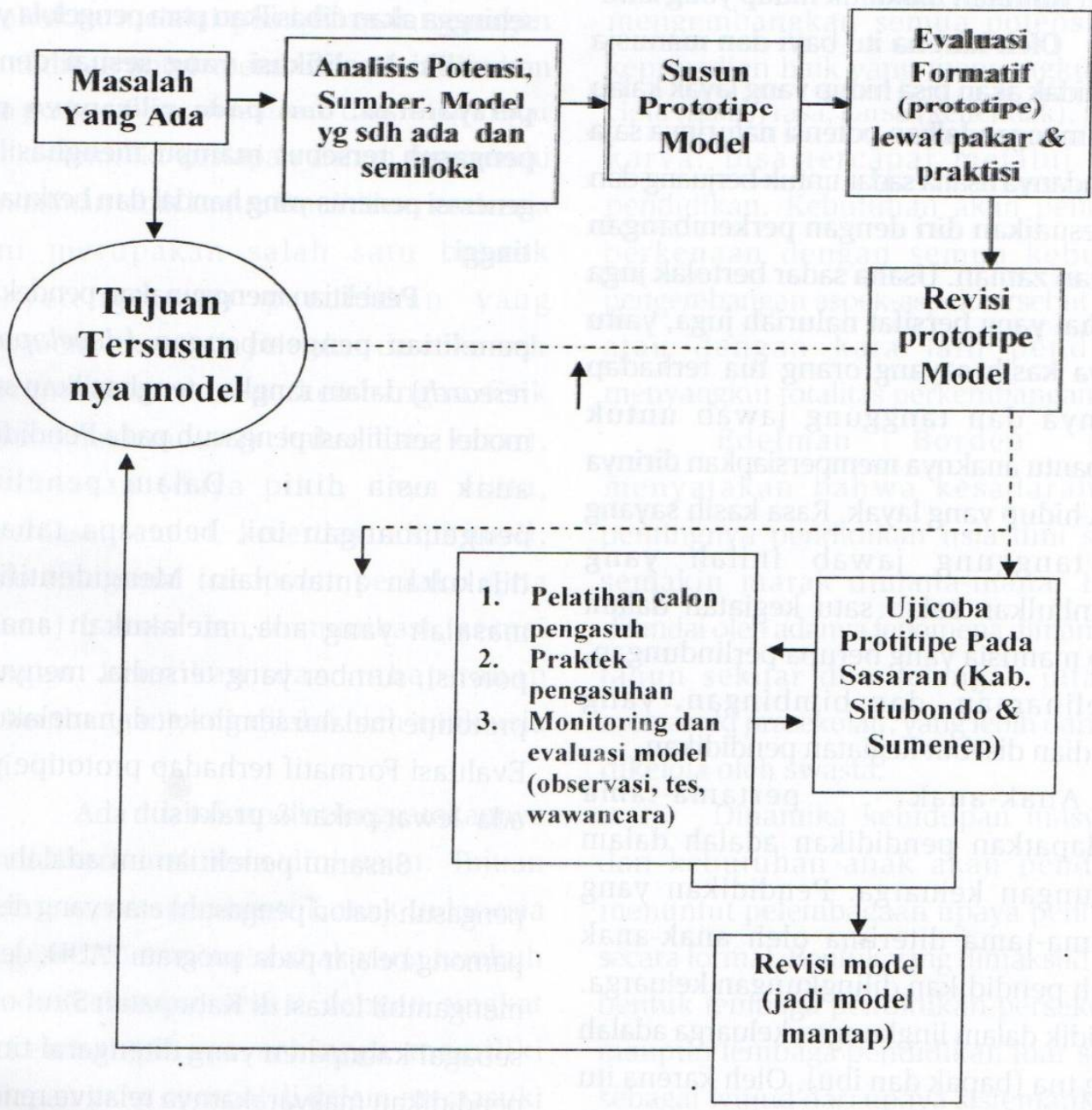

Gambar Alur Pengembangan Model 


\section{HASIL DAN PEMBAHASAN}

\section{Model Pelatihan Sertifikasi} Pengasuh PAUD ini dilaksanakan untuk memenuhi tenaga pendidik/pembimbing seperti yang disyaratkan adalah "Penyelenggara pendidikan anak dini usia sekurang-kurangnya memiliki satu orang tenaga pendidik. Tenaga pendidik sekurangkurangnya berpendidikan SLTA atau sederajat dan memiliki kemampuan di bidang pendidikan anak dini usia".

Jenis Tenaga Kependidikan pada pendidikan PAUD/Prasekolah pada jalur PLS meliputi: (a) Pengelola, yakni orang yang bertugas memberikan pengarahan serta bertanggung jawab atas penyelenggaraannya program di lembaga pelayanan PAUD, (b) Pendidik adalah orang yang melaksanakan kegiatan pendidikan Prasekolah di lembaga pelayanan PAUD, (c) Pengasuh adalah orang yang melaksanakan tugas pengasuhan dan perawatan lenmbaga pelayanan PAUD, khususnya di Penitipan Anak.

Tugas dari tenaga pendidikan pada pendidikan Prasekolah adalah sebagai berikut:

a. Menyusun satuan pembelajaran

b. Mengembangkan sarana belajar sesuai kebutuhan

c. Melakukan proses pembelajaran

d. Melakukan penilaian berdasarkan tolok ukur terhadap peserta didik sesuai dengan program pembelajaran

e. Membuat laporan perkembangan proses pembelajaran

f. Melaksanakan administrasi pembelajaran g. Membimbing, mengawasi dan memberikan arahan kepada peserta didik selama proses pembelajaran dilaksanakan

Penyusunan model sertifikasi, khususnya yang berkendaan dengan materi pembelajaran sertifikasi Pengasuh Pendidikan Anak Usia Dini di dasarkan pada ketentuan sebagai berikut: (1) Program pembelajaran pada TPA, KB, dan bentuk lain yang sederajat merupakan seperangkat program pembelajaran yang dilaksanakan secara fleksibel. (2) Program pembelajaran disusun berdasarkan tahap perkembangan anak. (3) Program pembelajaran pada TPA, $\mathrm{KB}$, atau bentuk lain yang sederajat bagi peserta didik yang berusia di bawah enam tahun diselenggarakan dengan mengupayakan kesiapan belajar peserta didik untuk memasuki pendidikan dasar. (4) Program pembelajaran dilaksanakan secara terpadu dengan memperhatikan kebutuhan dan kepentingan terbaik anak serta memperhatikan kecerdasan jamak. (5) Pengembangan program pembelajaran didasarkan pada prinsip bermain sambil belajar dan belajar seraya bermain dengan memperhatikan perbedaan bakat, minat, dan kemampuan masing-masing peserta didik, sosial budaya, serta kondisi dan kebutuhan masyarakat setempat. (6) Pengembangan program pembelajaran harus mengintegrasikan kebutuhan peserta didik terhadap kesehatan, gizi, dan stimulasi psikososial, termasuk kesejahteraannya.

Untuk membantu agar pendidikan terhadap anak tetap terpenuhi, perlu menyediakan layanan bagi anak melalui program pendidikan anak usia dini (PAUD), 
khususnya melalui kelompok bermain dan atau taman penitipan anak. Mengingat jumlah pelaksanan program PAUD masih sedikit, maka perlu peningkatan pelaksana program PAUD. Namun karena keterbatasan tenaga pengasuh/pengelola sudah waktunya jika dilakukan pelatihan bagi masyarakat yang memiliki minat untuk membuka layanan PAUD.

Tujuan sertifikasi tenaga pengasuh (pamong belajar-PAUD) adalah: Menyiapkan tenaga pengelola/pamong belajar/ pelaksana program PAUD secara profesional. Secara khusus sertifikasi pamong belajar pendidikan anak usia dini ini bertujuan agar peserta pelatihan (sertifikasi program PAUD) dapat: (1) memiliki wawasan dan dasar pemikiran tentang PAUD , (2) menguasai landasan psikologi anak usia dini,(3) mengidentifikasi masalah anak usia dini dan melaksanakan bimbingan anak, (4) memilih dan melaksanakan strategi pembelajaran PAUD, (5) mengembangkan kreatifitas, seni dan memilih permainan bagi PAUD, (6) memahami tentang kesehatan dan gizi anak usia dini, (7) mengelola program PAUD, (8) memiliki pengalaman dalam merancang dan melaksanakan PAUD

Latihan menjadi pamong PAUD dilakukan dengan simulasi yaitu masingmasing warga belajar praktek di depan teman-temannya sendiri mempraktekkan salah satu pokok bahasan yang akan diajarkan. Setelah selesai praktek, temanteman saling memberikan masukan dan yang bersangkutan juga menilai dirinya sendiri dengan mencocokkan pada masukan yang diberikan oleh teman-temannya dan juga oleh dosen/pelatih. Situasi yang terjadi diciptakan seddemikian rupa yang mirip dengan keadaan kelas kelompok bermain yang sebenarnya dan teman-teman berpurapura menjadi peserta didik pada kelompok bermain yaitu anak-anak.

Evaluasi hasil dilakukan pada peserta didik dengan memberikan test pada akhir semua pembelajaran. Materi test adalah tentang aplikatif dari semua materi pelatihan. Test ini diberikan pada 3 hari setelah semua pembelajaran diberikan. Hasil test dipakai sebagai dasar pemberian nillai pada sertifikasi.

Evaluasi proses juga dilakukan yaitu dengan menyebarkan angket pada peserta didik untuk memberikan masukannya tentang proses pembelajaran/ pelatihan yang telah dilaksanakan. Materinya meliputi peran yang dilakukan oleh pelatih/dosen terdiri atas: penampilan, penguasaan kelas, metode penyampaian, media, materi dan bahan ajar serta penyajian sistematika mengajar. Juga tentang tempat penyelenggaraan dan konsumsinya serta fasilitas yang lain yang seharusnya ada untuk peserta didik. Hasilnya akan dipakai sebagai masukan terhadap penyelenggaraan pelatihan sertifikasi Pengasuh PAUD yang akan datang dan juga di zasukkan dalam laporan penelitian.

Monitoring dilaksanakan dengan melakukan kunjungan di kelas dimana peserta didik sedang mengajar/memberikan bimbingan pada anak usia dini. Kegiatan ini dilakukan setelah proses pelatihan selesai. Peneliti mengamati peserta didik yang sedang mengajar, setelah itu hasil monitoring berupa catatan diberikan pada 
peserta didik (peserta pelatihan) sebagai masukan dan penyempurnaan kegiatan pembelajarannya.

Sesuai dengan rencana untuk mengetahui proses pembelajaran dilakukan penilaian atas kegiatan pembelajaran yang dilakukan. Evaluasi itu dilakukan terhadap materi, pembelajaran dan kepanitiaan sebagai penyelenggara, adapun sebagai evaluator adalah peserta didik sebagai sasaran kegiatan ini.

Untuk memaksimalkan hasil penelitian, peserta program sertifikasi ini akan dibatasi, setiap kelompok maksimum 20 orang. Hal ini dimaksudkan untuk memudahkan melakukan penilaian hasil belajar, karena penilaian didasarkan pada penilaian portofolio. Mereka yang direkrut adalah Lulusan SLTA atau yang sederajat. Peserta adalah warga masyarakat yang berkeinginan untuk menjadi pamong belajar pada Kelompok Bermain atau TPA. Lulusan diharapkan akan membantu pemerintah untuk menunjang pemerataan pendidikan anak usia dini khususnya di perdesaan. Oleh karena itu kegiatan ini dapat bekerjasama dengan pemerintah daerah.

Materi yang disusun berupa buku paket untuk kepentingan sertifikasi Pengasuh/pamong belajar pada pendidikan anak usia dini pada jalur nonformal meliputi: a) Konsep Dasar PAUD. b) Menu Asuhan Anak, c) Permasalahan dan Bimbingan Anak, d) Permainan \& Kreativitas Anak, e) Kesehatan dan Gizi Anak, f) Strategi Pembelajaran PAUD, g) Manajemen PAUD, dan h) PPL (praktek lapangan)
Metode Pembelajaran yang digunakan menggunakan model pengajaran langsung dengan pemodelan, ceramah, diskusi, pembelajaran berdasarkan pemecahan masalah, pengajaran kolaborasi. Untuk menunjang keberhasilan pembelajaran digunakan media pembelajaran berupa : buku paket, Hand out, Power point (dan LCD), . Evaluasi hasil belajar ditujukan pada penguasaan teori dan juga praktek (PPL), selain itu evaluasi juga didasarkan pada assesmen kelas, dan portofolio.

Dari hasil ujicoba dapat diketahui bahwa ada peningkatan pemahaman peserta serifikasi atas materi yang terkait dengan pendidikan anak usia dini, pada gilirannya dapat membuat mereka lebih baik dalam mengelola pendidikan anak usia dini.

\section{KESIMPULAN}

$$
\text { Pengembangan }
$$

program pembelajaran didasarkan pada prinsip bermain sambil belajar dan belajar seraya bermain dengan memperhatikan perbedaan bakat, minat, dan kemampuan masingmasing peserta didik, sosial budaya, serta kondisi dan kebutuhan masyarakat setempat. Metode Pembelajaran yang digunakan menggunakan model pengajaran langsung dengan pemodelan, ceramah, diskusi, pembelajaran berdasarkan pemẹcahan masalah, pengajaran kolaborasi. Untuk menunjang keberhasilan pembelajaran digunakan media pembelajaran berupa : buku paket, hand out, power point (dan LCD), VCD. Evaluasi hsil belajar ditujukan pada penguasaan teori dan juga praktek (PPL), selain itu evaluasi juga didasarkan 
pada assesmen kelas, dan portofolio. Hasil ujicoba program sertifikasi dapat dikategorikan baik untuk materi maupun untuk proses pembelajaran, hanya untuk penyelenggara termasuk kategori cukup baik. Bagi peserta sertifikasi yang menjadi sasaran monitoring (10 orang) dapat dinyatakan ada peningkatan dalam proses pembelajaran, ini merupakan salah satu indikator dari keberhasilan program. Pihak mitra merasa pentingnya program pelatihan seperti yang diselenggarakan saat ini, dan berharap selalu diadakan kegiatan sejenis untuk memenuhi kebutuhan pamong PAUD di daerah.

\section{DAFTAR PUSTAKA}

Edelman Borden, Marian. 1997. Smart Start: The Parents' Complete Guide to Preschool Education. Facts On File, Inc.New York,

Freire, P. (1997) Menggugat Pendidikan. Yogyakarta: Pustaka Pelajar.

Gordon, T. (1996). Mengajar Anak Berdisiplin Diri (di rumah dan di sekolah). Jakarta:

Pt.Gramedia.

Kamii \& Linda 1989. Young Children Continue to Reinvent Arithmetic. New York Teacher College Press

Nadesul, H. (1996) Cara Sehat Mengasuh Anak. Jakarta: Puspa swara

Nurhadi, Muljani A. 1997. Pembinanan Pendidikan Nasional berdasarkan UU Sistem Pendidikan Nasional dalam Rangka memenuhi tuntutan kebutuhan Pembangunan Nasional. Kertas kerja peserta kursus reguler Lemhanas Angkatan XXX tahun 1997)

Pangestu, Mari dan Ira Sestiadi (Penyunting, 1997). Mencari Paradigma Baru Pembangunan Indonesia Jakarta: Centre For Strategic and International Studies.

RPP Tentang PAUD

Sanusi, A. (1998) Pendidikan Alternatif. Bandung: Program Pascasarjana IKIP Bandung. Sihombing, U. (1999).Pendidikan Luar Sekolah Kini dan Masa Depan. Jakarta: Pd Mahkota. Sudjana, D. (1996).Pendidikan Luar Sekolah wawasan Perkembangan Falsafah dan Teori Pendukung asas. Bandung: Nusantara Press.

Suryabudhi, M. (1993). Cara Merawat Bayi dan Anak-anak. Bandung: Cv Pionir Jaya. Tangyong, 1987. Pengembangan Anak Usia Taman Kanak-kanak. Gramedia Jakarta UU No 20 Tahun 2003, Tentang Sistem Pendidikan Nasional

Utomo,B. (1998). Dampak Krisis Moneter dan Kekeringan Terhadap Status Kesehatan \& Gizi Anak. Kumpulan Makalah Seminar. Jakarta: PPT.LIPI. 